\title{
Gram per Second
}

National Cancer Institute

\section{Source}

National Cancer Institute. Gram per Second. NCI Thesaurus. Code C85603.

Grams per second. 